\title{
Climate finance and green growth: reconsidering climate-related institutions, investments, and priorities in Nepal
}

Tek Jung Mahat ${ }^{1,2}$, Luděk Bláha', Batu Uprety ${ }^{3}$ and Michal Bittner ${ }^{1 *}$ (D)

\begin{abstract}
Nepal, a least-developed, mountainous, and land-locked country is consistently ranked as one of the most vulnerable countries to the climate change. Poor socioeconomic development, rough and highly unstable geography, inadequate institutional capacity to deal with research, development and policy and mostly underdeveloped infrastructures, all have contributed to increasing vulnerability of communities and ecosystems, and have limited their adaptive capacity. Over the past decade, Nepal has made significant progress, particularly in developing and implementing policies and frameworks and establishing institutional mechanisms with the support of donor countries, UN and multilateral agencies. As the global climate politics is getting more complicated, international financing patterns-both climate and development finance-are shifting their ways, forcing the countries like Nepal to diversify the funding base for climate change actions and integrate them within national development plans and strategies. Using the data and information currently available, we analyze the existing financing situations, discuss the future scenarios and suggest policy recommendations to develop a set of long-term adaptation and impact mitigation strategies in specific and environmental change at large. When short-term adaptation strategies funded from existing financial arrangements and other related bilateral and multilateral sources particularly European countries, seem to be encouraging, we stress the need of "public-private partnership-driven full-fledged green economy" focusing on renewable energy and transport, agriculture and forestry, water and water-induced disasters, as well as tourism and hospitality.
\end{abstract}

Keywords: Climate change adaptation, Climate finance, Climate investment, Green economy, European Union

\section{Background}

"Climate finance (CF)", or "finance for climate changerelated activities," is a diverse concept and does not have a clear definition or well-elucidated scope. CF, in recent decades, has become a dominant instrument in shaping the way the international community interacts with each other, explores the means of development cooperation, and defines common approaches to solve the global climate crisis individually or collectively at a local, national, regional and global scale. When several attempts to define, compare, and contrast CF with development

\footnotetext{
${ }^{*}$ Correspondence: michal.bittner@recetox.muni.cz

${ }^{1}$ Faculty of Science, Research Centre for Toxic Compounds

in the Environment-RECETOX, Masaryk University, Kamenice 5, 62500 Brno, Czech Republic

Full list of author information is available at the end of the article
}

finance have ended inconclusively, the evolving concept of "additionality of CF" has added another layer of confusion to it. CF is a highly political and hotly contested issue during climate change (CC) negotiations [1] such as in United Nations Framework Convention on Climate Change (UNFCCC), Kyoto Protocol and Paris Agreement, something neither the Parties can ignore, nor they can come up with any easy and practical solutions. Noting that the largest share of historical and current global emissions of greenhouse gases (GHGs) has originated in developed countries that industrialized first, the UNFCCC recognizes the need of "new and additional" finance from developed countries to help developing countries prepare for climate actions as appropriate and urges such means of cooperation to be agreed among all the Parties [2]. Building on the UNFCCC texts, the least-developed 
country (LDC) negotiators demand for "polluters pays" principle-driven additional funding clearly labeled as CF on top of the official development assistance (ODA). However, the other group, the Organisation for Economic Co-operation and Development (OECD) donors, stresses the similarities between CF and ODA and point to the need for "climate-proofed" development finance [1]. Learning lessons from past experiences with the development finance, they stress that the CF should be more effectively delivered and successful in securing more development benefits while addressing the fundamental needs to tackle the CC problem $[1,3]$.

Since the area of CF is still emerging and lacks an international coordination body such as for the ODA, it is either discussed separately or in connection with related and overlapping concepts of green finance, sustainable finance, low-carbon finance, or climate-related development finance [4]. Moreover, it is important to distinguish between different types of international CFs-adaptation and mitigation, and recipients of these funds-LDCs versus middle-income countries $[1,5,6]$. Keeping this in mind, it is stressed that the Parties promote trust and confidence in meeting earlier CF commitments to ensure pre-2020 CF is effectively disbursed and utilized and post-2020 CF issues are realistically planned [7].

Being source of a mere $0.027 \%$ of the GHGs emission and home for circa $0.37 \%$ of world population, Nepal is consistently ranked as one of the most vulnerable countries to the CC [8-12]. Nepal is already exposed to the worst impacts of CC in the form of melting Himalayas to the flooding plains, degrading lands to disappearing biodiversity, and increasing natural disasters to the poor adaptive capacity of its population [13]. Thus, it is seeking international support and resources to address these climate-induced challenges in various forms of cooperation-financial, technology development and transfer, knowledge enhancement, capacity building, and so on. More than $80 \%$ of such resources are aimed to be spent on the ground, serving the most climate vulnerable people and communities, as stipulated in Nepal's Climate Change Policy (2011).

Nepal is a party to the UNFCCC, Kyoto Protocol and the Paris Agreement, and is active in various UN and other regional organizations linked to the CC issue [12], and has already prepared several adaptation programs and policies (Table 1). Currently, Nepal is formulating the National Adaptation Plan (NAP) [14]. Nepal's most efforts in the past three decades have focused on forest conservation, disaster risk management and in creating an enabling environment to take effective actions for CC impacts, particularly in developing required policies, setting up appropriate institutions in place, and developing more scientific knowledge about different aspects of CC impacts. The future course of actions in the country is likely to be guided by its commitment to implement the Paris Agreement 2015, and in the core of it, Nationally Determined Contributions (NDCs). Nepal's NDCs were submitted to the UNFCCC secretariat in 2016 with a range of instruments identified to enhance actions to address CC in the form of 14-points contributions (Table 2) [15].

Table 1 Nepal membership and adapted policies related to the CC area

\begin{tabular}{ll}
\hline Nepal membership in UN or regional organizations linked to CC & Initial year \\
\hline International Centre for Integrated Mountain Development & 1983 \\
South Asian Association for Regional Cooperation & 1985 \\
Global Environment Facility (GEF) & 1988 \\
Asia Pacific Adaptation Network & 2009 \\
Adapt Asia-Pacific & 2012 \\
United Nations Environment Programme & 2015 \\
Intergovernmental Panel on Climate Change & n.a. \\
Adaptation programs and policies linked to CC in Nepal & 2004 \\
Initial National Communications through the UNFCCC Secretariat & 2008 \\
Pilot Program for Climate Resilience (PPCR) & 2010 \\
National Adaptation Programme of Action & 2011 \\
National Framework on Local Adaptation Plans for Action (LAPA) & 2011 \\
Climate Change Policy & 2011 \\
Strategic Programme for Climate Resilience (SPCR) & 2012 \\
Climate Change Budget Code & 2014 \\
Second National Communications through the UNFCCC Secretariat & \\
\hline
\end{tabular}

n.a. not available 
Table 2 Nepal's Nationally Determined Contributions (NDCs) and their links with Sustainable Development Goals (SDGs) $[15,16]$

\begin{tabular}{|c|c|c|}
\hline Nepal's NDCs, October 2016 & Targeted & Corresp. SDGs ${ }^{\mathrm{a}}$ \\
\hline 1. Formulate and implement NAPs & 2020 & 13 \\
\hline 2. Enhance implementation of Environment-Friendly Local Governance Framework & n.a. & $5,10,13,16,17$ \\
\hline 3. Promote scientific approaches for understanding and dealing with CC impacts & n.a. & 13 \\
\hline 4. Improve understanding of CC-related loss and damage & n.a. & 13 \\
\hline $\begin{array}{l}\text { 5. Formulate Low-Carbon Economic Development Strategy to promote economic development focusing } \\
\text { on: (I) energy; (II) agriculture and livestock; (III) forests; (IV) industry; (V) human settlements and wastes; (VI) } \\
\text { transport; and (VII) commercial sectors }\end{array}$ & n.a. & All \\
\hline 6. Achieve $80 \%$ electrification through renewable energy and reduce dependency on fossil fuels by $50 \%$ & 2050 & $3,7,8,9,11,12,13$ \\
\hline $\begin{array}{l}\text { 7. Achieve the targets of mini and micro hydropower ( } 25 \mathrm{MW}) \text {, solar home systems }(600,000) \text {, institutional } \\
\text { solar power systems (1500), improved water mill }(4000) \text {, improved cooking stoves }(475,000) \text {, and biogas } \\
\text { (130,000 households, } 1000 \text { institutional and } 200 \text { community plants, under the National Rural and Renewable } \\
\text { Energy Programme, 2012-2017), and reducing dependency on biomass and making it more efficient }\end{array}$ & 2017 & $7,8,9,11,12,13$ \\
\hline 8. Expand the energy mix focusing on renewables by $20 \%$ and diversify energy consumption pattern & 2020 & $7,8,9,11,12,13$ \\
\hline 9. Increase the share of the electrical vehicles up to $20 \%$ from the 2010 level & 2020 & $3,9,11,12,13$ \\
\hline 10. Decrease dependency on fossil fuels in the transport sector by $50 \%$ & 2050 & $3,7,9,11,12,13$ \\
\hline 11. Develop electrical rail network supporting mass transport & 2040 & $3,9,11,12,13$ \\
\hline 12. Maintain $40 \%$ forest cover in the country & Throughout & $3,6,11,12,13,14,15$ \\
\hline $\begin{array}{l}\text { 13. Pilot a sub-national Reducing Emissions from Deforestation and Forest Degradation (REDD }+ \text { ) project } \\
\text { reducing about } 14 \text { million tons of } \mathrm{CO}_{2} \text { equivalent }\end{array}$ & 2020 & $3,11,12,13,14,15,16,17$ \\
\hline 14. Decrease the rate of air pollution by 2025 & 2025 & $3,6,9,11,12,13,15$ \\
\hline
\end{tabular}

SDGs 2016-2030: 1-no poverty, 2-zero hunger, 3-good health and well-being for people, 4-quality education, 5-gender equality, 6-clean water and sanitation, 7-affordable and clean energy, 8-decent work and economic growth, 9-industry, innovation and infrastructure, 10-reduced inequalities, 11sustainable cities and communities, 12-responsible consumption and production, 13—climate action, 14-life below water, 15-life on land, 16-peace, justice and strong institutions, 17-partnerships for the goals

n.a. not available/not set

a SDGs 1, 2, 3, 4, 5, 14, 15, 16 and 17 have much broader objectives and have indirect two-way linkages with each of the NDCs

This paper has threefold objectives (I) understanding the composition and trends of CF at global level; (II) reviewing the current status of CF in Nepal; and (III) proposing future pathways for the country considering Nepal's commitment to the Paris Agreement through NDCs, the 2030 Agenda for Sustainable Development and the sustainable development goals (SDGs). Here we analyze a range of interventions that are on their way both at the world level and in Nepal, discuss their future implications, and make suggestions to develop long-term adaptation and mitigation strategies in specific and environmental change at large.

\section{Data and methods}

The main sources of data and information used for this analysis are periodic updates from the UNFCCC Standing Committee on Finance, the Government of Nepal's line ministries and dedicated agencies, the Climate Policy Initiative and the European Union (EU). Additionally, information available from public domains are also considered including those of UN agencies, the World Bank (WB), the OECD, the International Energy Agency and other agencies, that are, either contributing to, or benefitting from, or closely monitoring CF globally and in
Nepal. Similar to its definition, CF flow figures also vary from source to source and are open to different interpretations. The figures used in the present paper are in line with UNFCCC understanding about CF and are aimed at giving an idea on how things are transforming and also to provoke further debate on CF in Nepal.

\section{Global landscape of climate finance}

The UNFCCC official estimates show that the global CF increased by almost $15 \%$ from US $\$ 650$ billion in 2011/2012 to US\$741 billion in 2014 [17] (Fig. 1). If we are to maintain the global average temperature below $2{ }^{\circ} \mathrm{C}$ above the pre-industrial levels (green growth scenario), we need significant growth in green infrastructures investment as recommended by the Green Growth Action Alliance presentations at the World Economic Forum 2013 in Davos. When the business as usual investment of US\$5 trillion/year is estimated in agriculture, forestry, water, energy, settlement, industries, telecoms and transport sectors by 2020 , additional US $\$ 0.7$ trillion/year or $14 \%$ investment is required in settlement, industries, energy, forestry, and transport sector to meet the green growth scenario [18]. The details on 


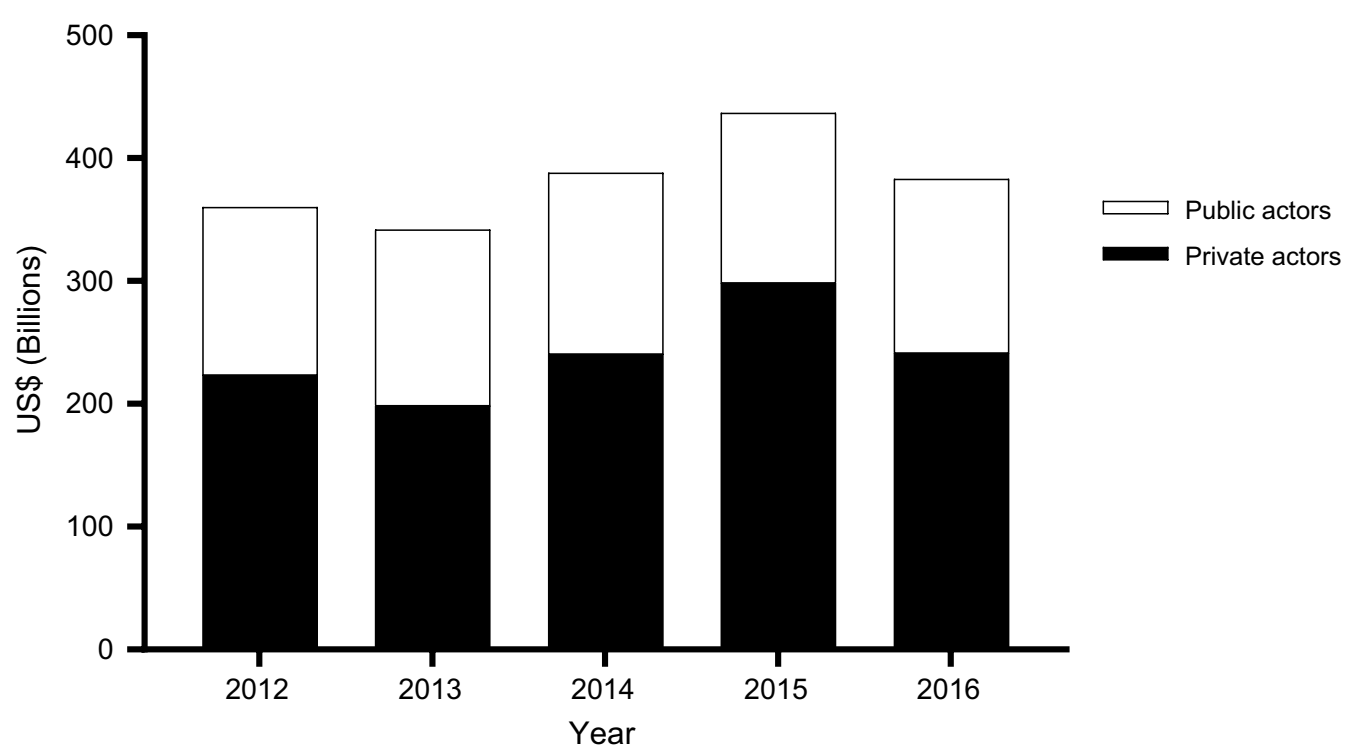

Fig. 1 Global climate finance (2012-2016) [19]

the distribution of investments from public and private sources are described in Additional file 1.

\section{Mitigation vs adaptation}

Between 2015 and 2016, 93\% of the CF was invested in mitigation activities to reduce GHGs emissions, of which, $74 \%$ went to the renewable energy sector alone [19]. This trend, combined with the global redistribution of investment in the energy sector, was characterized by fall of $38 \%$ in capital spending in the fossil fuel supply sector between 2014 and 2016, making the electricity sector the largest recipient of energy investment in 2016 for the first time ever. The same period also saw low-carbon alternatives, including electricity networks, increasing their share of total supply-side investment to $43 \%$, with a net increase of $12 \%$. This was triggered by private investment in renewable electricity generation exceeding new investment for fossil fuel power generation by over 100\% for 2015 and 2016 [19, 20]. Energy efficiency (39\%), renewable energy generation (34\%), and sustainable transport $(22 \%)$ are top three spenders in the mitigation sector, whereas agriculture, forestry, land-use, and natural resource management activities spend only $3 \%$ of the total resource [19]. Increased investments in mitigation activities are also evident in changing climate financing patterns in Nordic countries where the mitigation will continue to remain a top priority for many decades to come [21].

Buchner et al. [19] show that adaptation sector received about $16 \%$ share of public CF in 2015/2016, with a slight reduction from $18 \%$ in $2013 / 2014$. This is despite some
$29 \%$ increase in commitments from the multilateral donors, coinciding with almost $50 \%$ reduction in commitments from the national DFIs. Water and wastewater management (11\%), agriculture, forestry, land-use, and natural resource management (4\%), and disaster risk management (2\%) are the three top spenders in the adaptation sector, while infrastructure, energy, and other built environment sectors attract only $2 \%$ of the resources [19]. CF update 2017 estimates some $25 \%$ of the financing approved since 2003 might have gone for adaptation activities with Least Developed Countries Fund (LDCF), PPCR, The Green Climate Fund (GCF), adaptation fund (AF), Adaptation for Smallholder Agriculture Program and Special Climate Change Fund (SCCF) accounting for 553 projects worth US\$3.91 billion. The approved funding is much less than the original adaptation finance pledges made by developed countries with top pledgersUK, Germany, and the USA alone are responsible for $57 \%$ [22].

\section{European contribution}

Figure 2 shows contributions of the UNFCCC Annex II Parties (mainly OECD and EU) to the UNFCCC Non-Annex I Parties (developing countries), which has increased up to $150 \%$ between 2011 and 2014. This is in response to the urgency of actions in developing countries, and increased pressure developed by them within the UNFCCC system, including the claim that the developed countries are responsible to a major part of the climate problems in the spirit of the Convention whereas the developing and low-income countries suffer the most 


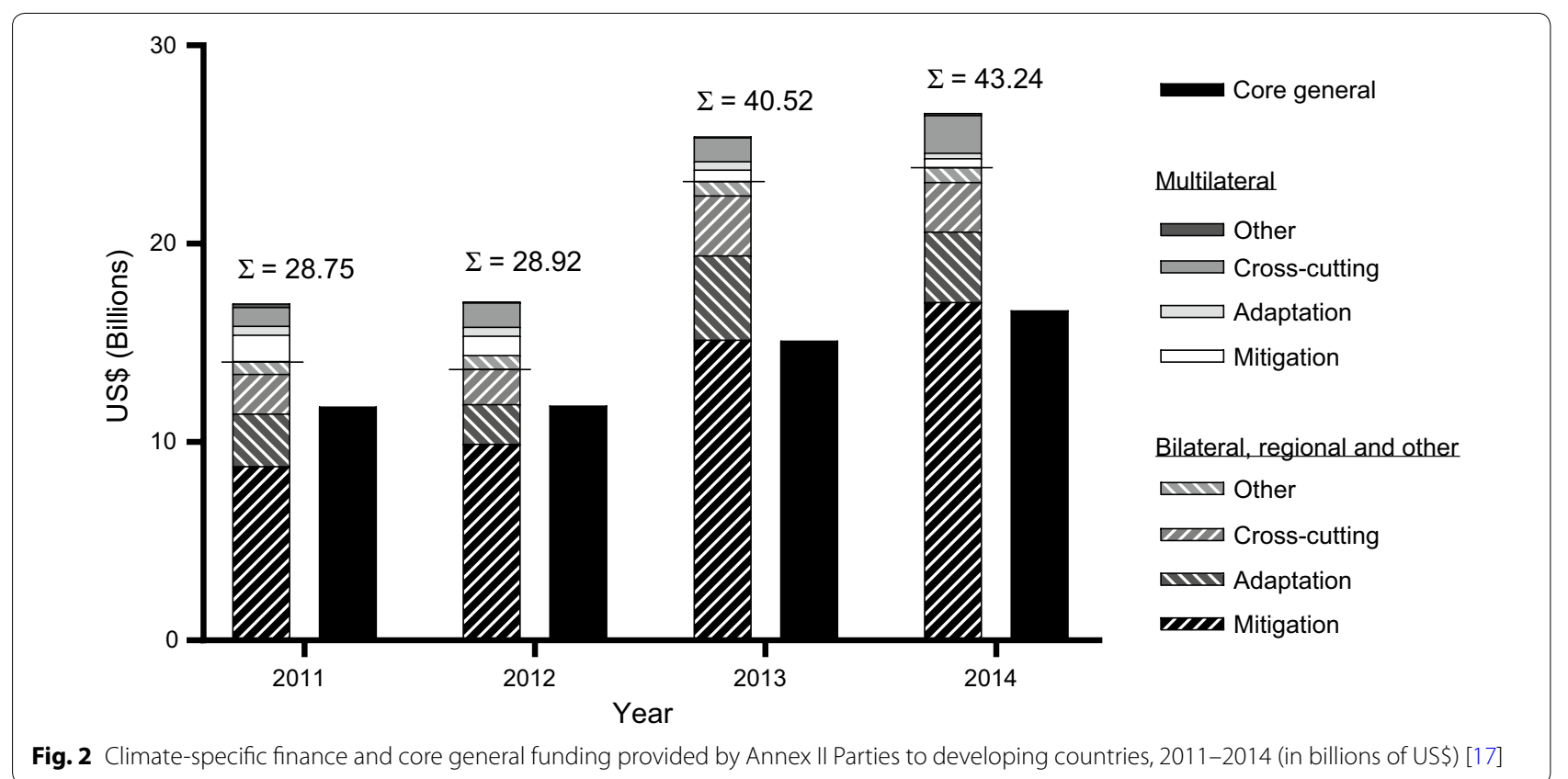

from CC impacts. Therefore, the developed countries should sufficiently finance climate actions in developing countries while ensuring necessary GHGs emission reduction actions back home.

EU sees its contribution as an instrument to incentivize climate-resilient and low-carbon investments while maintaining complementarity with domestic resources [23]. Therefore, it invests a large number of financial resources to tackle climate issues at home and in helping the poorest and most vulnerable countries mitigate, adapt and build resilience to CC [24]. As featured on the EU CF portal [23], it has provisioned two modes of support-direct grant funding to the poorest and most climate vulnerable countries; and use grant to leverage private investment by combining grants with other loans and equities from public and private sectors, including the bilateral and multilateral banks/agencies. Innovative Financial Instruments present a set of blending facilities EU, and its member states have offered to combine grant funding with loans for different regions in the world [23].

The EU and its member countries are the largest contributors to the UNFCCC and Kyoto Protocol related funds, including up to $80 \%$ of the LDCF and the SCCF (cumulative funding of US\$907 and US\$344 million, respectively), over $90 \%$ of the cumulative contributions to the AF, and approximately $50 \%$ of the UN-GEF cumulative pledges from 1991 to 2014, estimated around US\$2 billion for CC [25]. The EU has planned to spend at least $20 \%$ (US $\$ 256.53$ billion, i.e. $€ 217.4$ billion with a conversion rate of US\$1.18 per $€$ ) of the EU budget on climate-related actions in the period 2014-2020 [26, 27].
When the majority of this will be spent in the cohesion and agricultural areas, US\$9.32 billion ( $€ 7.9$ billion) is allocated to be spent directly in the areas of $\mathrm{CC}$ and risk [26]. Similarly, US $\$ 16.52$ billion ( $€ 14$ billion), an average of US $\$ 2.36$ billion ( $€ 2$ billion) per year is earmarked to support activities in developing countries alone [23]. This estimate is double to the 2012-2013 level spent for the same purpose, which is secured through increased commitments from the EU, its member states and the European Investment Bank to address $C C$ impacts $[23,26]$.

Launched in 2007, the Global Climate Change Alliance Plus $(\mathrm{GCCA}+)$ is an EU flagship initiative with a strong focus on highly vulnerable LDCs and Small Island Developing States. GCCA+ has already invested close to US\$531 million ( $€ 450$ million) in more than 60 country-based and regional actions, including the US\$19.47 million ( $€ 16.5$ million) contribution to Nepal Climate Change Support Programme (NCCSP) from 2013 to 2015 (GCCA+: $€ 8.6$ million incl. $€ 0.6$ million Fast Start Finance (FSF) from Cyprus, Department for International Development (DFID): €7.9 million) [23, 28].

EU External Investment Plan, an initiative to invest in EU's partner countries in Africa and the EU Neighborhood region, aims to leverage more than US\$51.92 billion ( $€ 44$ billion) of additional investments by 2020, on top of the 'Juncker Plan', that has already triggered US $\$ 246.62$ billion ( $€ 209$ billion) of investment [23]. In the year 2016, EU and its member states together with other donors, presented a Roadmap to US\$100 billion, and EU remains committed to this goal of jointly mobilizing, together with other developed countries, the US\$100 billion per 
year fund by 2020 to support the developing countries [29]. The Paris Agreement extended this level of contribution through 2025, prior to which a new collective goal is expected to be agreed [30]. GCF, established under the UNFCCC in 2010 to support developing countries to reduce GHGs emission and adapt to $\mathrm{CC}$, has received pledges worth US $\$ 10.3$ billion since 2014, of which, almost half of it is pledged by the EU member states, who stands at US $\$ 4.8$ billion. Additionally, some EU member states and regions are making up to $95 \%$ of the annual voluntary pledges for the smooth and effective operation of the AF [23].

\section{Climate finance in Nepal}

There is a very complex process involving different sources, agents, and channels for CF to enter Nepal, making it difficult to track "relative contributions" through each channel and present them accurately [31]. When the traditional ODA channels top the list, other five channels: a national entity specifically for CF; new and additional public finance from industrialized countries; the emerging (but uncertain) carbon market; private sector investment and resources made available through the national budget, make an important part of the contributions [31].

According to the economic impact assessment in 2013 focusing on three key sectors-agriculture, hydroelectricity, and water-induced disasters, the climate-induced extreme events, such as floods, droughts, soil erosion, and agricultural production loss, have led to a major economic loss in Nepal. Direct costs of these events are estimated to be in the range of US\$270-360 million for the year 2013 (1.5-2\% of Gross Domestic Product-GDP) with an anticipated loss of as much as US\$62.384 billion or $2-3 \%$ of GDP by the year 2050 [32]. The impact of water-induced disasters, such as flood and droughts, is not limited to basic human activities for living, but includes effect on hydrodynamic and morphodynamic processes in the water, with severe consequences to flora and fauna, water quality, water and sediment structures, soil moisture, irrigation requirements, soil contamination and fertility, geomorphology, and overall ecosystem at large [32, 33]. Such disasters often draw socioenvironmental tensions around these topics and add pressure for new and additional resources making the consequences even worse and economically difficult to maintain [3234]. Therefore, Nepal needs an additional investment of at least US $\$ 2.4$ billion from now to 2050 to build a sufficient climate resilience [32, 35].

\section{Domestic climate finance}

When the Climate Public Expenditure and Institutional Review first started in 2011, CC-related activities in Nepal accounted only for almost $2 \%$ of GDP and around
$6 \%$ of total government expenditure, of which, threequarters is related to adaptation activities [36]. When the share of CC-related expenditure in national budget is increasing, it is seen that four ministries-physical planning and works, local development, irrigation, and environment alone were found to be responsible for $77 \%$ and $87 \%$ of planned and actual expenditure, respectively, over the reviewed period, of the total ten ministries directly involved in taking climate actions [36, 37]. Figure 3 summarizes the recent scenario of $\mathrm{CC}$ budget within the ten most relevant ministries. Apart from them, a significant portion of the CC-related funding is also spent through the non-governmental organizations (NGOs) and community-based organizations as presented in Table 3.

\section{International climate finance}

Bird [31] also takes note of a preliminary list of donors' support for climate actions in Nepal (categorized as ODA), that shows US $\$ 652.40$ million of international public grant (for 71 different initiatives) was made available between 1997 and 2014, of which approximately 67\% resources came from two Multilateral Development Banks (MDBs)-Asian Development Bank (ADB) and WB alone. Contributions from the EU, additional contribution from selected EU member states Denmark, Finland, Germany, and the UK, and other non-EU European partners Norway and Switzerland accounted for 31\% of the budget, making the European Community second largest climate financer in Nepal after the MDBs [31]. When Japan accounted for another $1 \%$ of the resources, the UN contributed only $0.38 \%$. Of the 71 initiatives, more than 30 focused on capacity building and awareness raising. Mitigation and adaptation activities remained the focus of some 30 initiatives.

Following to the UNFCCC COP 15 pledge by the developed countries to provide "new and additional resources for CC actions" in the form of FSF, Nepal received some US $\$ 8.3$ million directly and shared additional US $\$ 145.5$ million with more than 19 other countries, as summarized in Table 4. Coincidently, all the corresponding donors are from the EU, making the EU the most important climate financer in Nepal [31].

Furthermore, over the last two decades and mostly in the 2010s, Nepal has received around US\$270 million, mostly for adaptation activities as part of 24 major projects and programs with thematic focus on forest and watersheds management, renewable energy and urban transport, ecosystem-based adaptation, glacier risk reduction, food security, smart agriculture and sustainable livelihoods and rural technologies [43]. Interestingly, US\$223 million (83\%) of this funding has come from non-UNFCCC multilateral financial institutions and MDBs (mostly from Climate Investment Funds-CIF, 


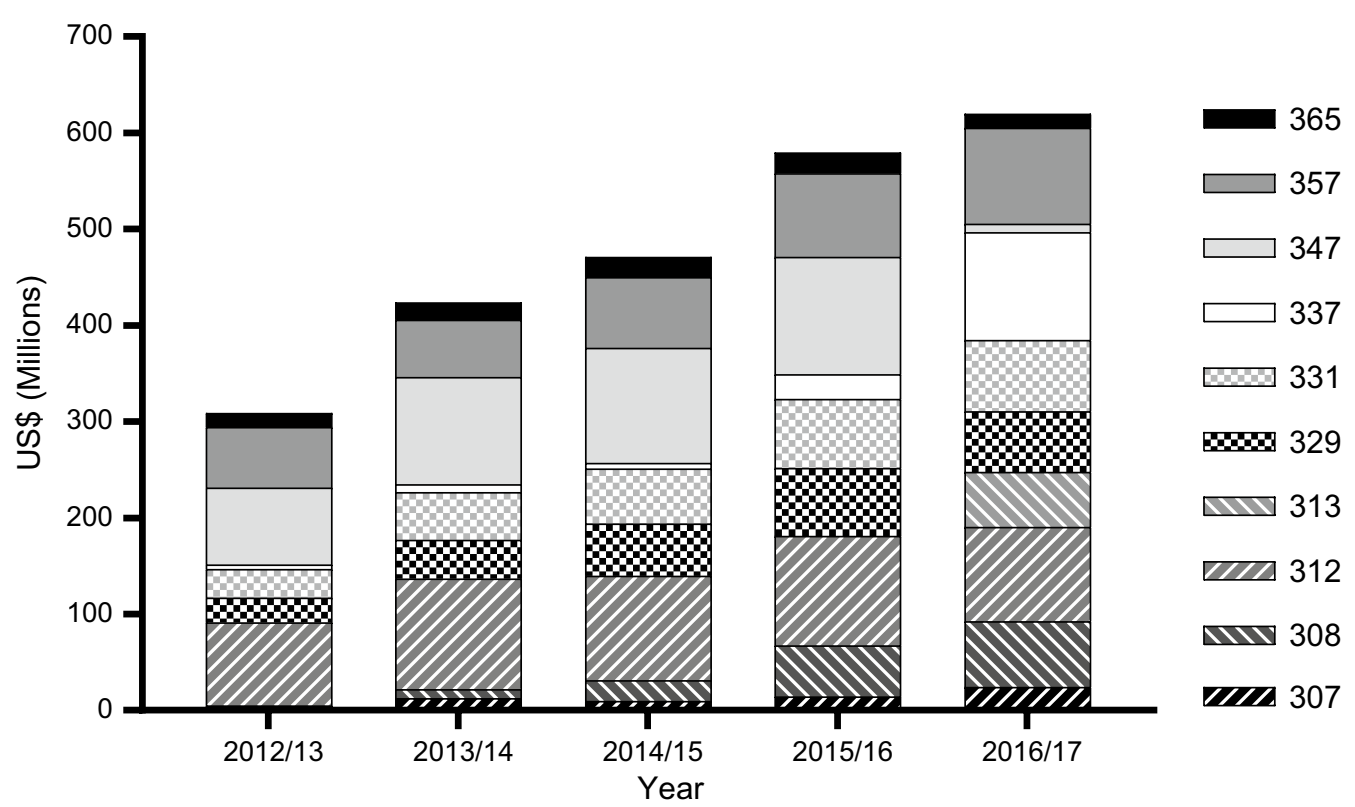

Fig. 3 Nepal's annual budgeting on CC [38-42]. Budget codes refer to following ministries: industry -307; energy-308; agriculture development-312; supply and sanitation-313; forestry and soil conservation - 329; science, technology and environment/population and environment-331; physical infrastructure and transport-337; urban development-347; irrigation - 357; federal affairs and local development-365. Original data is available in Nepal Rupees (NPR) only. Further details on structuring and restricting of ministries and NPR to US\$ conversion rate in presented in Additional file 2: Table S1

Table 3 CC expenditure in Nepal through NGOs (figures in thousands of US\$) [36]

\begin{tabular}{|c|c|c|c|c|c|c|}
\hline & Activities & Donor & $2009 / 10$ & $2010 / 11$ & $2011 / 12$ & $2012 / 13$ \\
\hline 1 & $\begin{array}{l}\text { Develop Community Forestry Payment Mechanism } \\
\text { (Federation of Community Forestry Users Nepal } \\
\text { and Asia Network for Sustainable Agriculture and } \\
\text { Bioresources) }\end{array}$ & $\begin{array}{l}\text { Norwegian Agency for Development Coop- } \\
\text { eration (NORAD) }\end{array}$ & 200 & 200 & 200 & 200 \\
\hline 2 & Carbon payment fund & NORAD $^{\mathrm{a}}$ & & 100 & 100 & 100 \\
\hline 3 & Grass-root capacity building for REDD+ & RECOFTC — The Center for People and Forests & & 91 & 91 & 91 \\
\hline \multirow[t]{2}{*}{4} & Social and environmental project & CARE Denmark & & 50 & & \\
\hline & Total & & 200 & 441 & 391 & 391 \\
\hline
\end{tabular}

${ }^{a}$ This fund is piloting the development of payment mechanisms for REDD+

WB, ADB) and bilateral donors (USAID, UK-Aid, and DANIDA), and not necessarily from UNFCCC financial institutions such as the LDC Fund, SCCF, GCF, AF, and the GEF. A comprehensive list of the projects is provided in the additional file based on inputs from NRDI-PRC assessment as well as on the information available on respective project Web sites (Additional file 3: Table S2).

However, there are also a few missed opportunities Nepal has not utilized. For example, during recent three GEF project cycles $(4,5$, and 6$)$, Nepal has constantly failed to fully utilize the money allocated through the System for Transparent Allocation of Resources. When Nepal was allocated US\$24.29 million under three headings (CC, biodiversity and land degradation), it hardly utilized $79 \%$ of the available resource (US\$19.28 million) [43].

\section{Management and visioning of climate finance}

Over last two decades, Nepal has been able to mobilize significant amount of climate and climate-related development finance from a range of national and international development partners and mechanisms, such as: (I) CIF, implemented by the MDBs; (II) funding available from UN and multilateral agencies under the UNFCCC mechanisms, including to implement the Kyoto Protocol; (III) support from bilateral donors; and (IV) global 


\begin{tabular}{|c|c|c|c|c|c|c|}
\hline Donor & Beneficiary country & Thematic areas & Project title & $\begin{array}{l}\text { Implementation } \\
\text { period }\end{array}$ & $\begin{array}{l}\text { Implementing } \\
\text { agency }\end{array}$ & Contribution $^{\mathrm{a}}$ \\
\hline Cyprus & Nepal & Adaptation & $\begin{array}{l}\text { EU/DFID: building } \\
\text { climate resilience in } \\
\text { Nepal }\end{array}$ & $\begin{array}{l}36 \text { months after sign- } \\
\text { ing the agreement }\end{array}$ & $\begin{array}{l}\text { Department for Inter- } \\
\text { national Develop- } \\
\text { ment (DFID) }\end{array}$ & 0.80 \\
\hline EU & Nepal & Adaptation & $\begin{array}{l}\text { Building climate resil- } \\
\text { ience in Nepal }\end{array}$ & 2011-2013 & DFID & 9.29 \\
\hline Finland & Nepal & Adaptation & $\begin{array}{l}\text { Increased capacity } \\
\text { hydro-meteoro- } \\
\text { logical services ICl } \\
\text { project }\end{array}$ & 2010-2012 & $\begin{array}{l}\text { Finnish Meteorologi- } \\
\text { cal Institute }\end{array}$ & 0.66 \\
\hline Germany & Nepal (+3 countries) & Adaptation & $\begin{array}{l}\text { FSF of adaptation to } \\
\text { CC in Asia }\end{array}$ & July-December 2010 & $\begin{array}{l}\text { German Corporation } \\
\text { for International } \\
\text { Cooperation (GIZ) }\end{array}$ & 3.58 \\
\hline Netherlands & Nepal (+16 countries) & Mitigation & $\begin{array}{l}\text { Energizing develop- } \\
\text { ment }\end{array}$ & 2009-2013 & $\mathrm{GlZ}$ & 90.24 \\
\hline Netherlands & Nepal ( +5 countries) & Mitigation & $\begin{array}{l}\text { Scaling up renewable } \\
\text { energy program in } \\
\text { low-income coun- } \\
\text { tries (SREP) }\end{array}$ & 2009-2013 & World Bank & 71.66 \\
\hline Netherlands & Nepal +20 countries) & $\begin{array}{l}\text { Adaptation and } \\
\text { mitigation }\end{array}$ & Climate resilience & 2009-2014 & $\begin{array}{l}\text { Red Cross and Red } \\
\text { Crescent }\end{array}$ & 27.60 \\
\hline UK & Nepal & All & $\begin{array}{l}\text { Support to CC pro- } \\
\text { gram }\end{array}$ & 2010-2011 & - & 0.27 \\
\hline
\end{tabular}

a Converted from $€$ to US\$ using the historical annual average exchange rate for the year 2010 ( $€ 1=$ US\$1.33)

and regional projects whose parts of the activities are implemented in Nepal. Although the funding Nepal has received so far is very small in comparison to its actual needs, available funding has, at least, enabled Nepal to start much-needed responses to CC challenges and better prepare for additional climate funding it requires. Thus far, Nepal has been able to commission scientific assessments of CC, improve and document CC knowledge base; set up institutional response mechanisms and strengthen institutional capacity; develop policy instruments and frameworks; implement selected pilots; and advocate the issue internationally $[11,12,14,15]$.

Building on successful intensive stocktaking exercise and finalization of NAPA in 2010, Nepal established a vision for $\mathrm{CF}$ for future and identified 11 priority areas for action by 2020 (Additional file 4: Table S3) together with responsible lead national institutions identified to operationalize them [31]. Introduced in 2012, the Climate Change Budget Code (CCBC) uses 11 criteria to define climate-relevant programs in Nepal (Additional file 5: Table S4) and helps track climate-relevant budget at the national level, according to which at least 11 of the then 27 ministries had CC relevant programs [44, 45]. CC budget allocated for the fiscal year 2013/14 was $10.3 \%$ of the total budget and $3.1 \%$ of the total GDP, significantly higher than the preceding year which was $8.88 \%$ of the total budget and $2.7 \%$ of GDP [45].

\section{Green economy and future climate investment opportunities in Nepal}

Nepal, home to the several mountain ranges including the Mount Everest, is key to secure global and regional climate regulation and to ensure water, energy and hydrological services to almost a billion people in South Asia. Rich in biological, cultural, religious, spiritual, and recreational resources, Nepal is eager to transit to lowcarbon economy by combining the green economy and $\mathrm{CC}$ actions [46]. The green economy is an economic system to achieve improved human well-being and social equity through enhanced use of environmental resources with no or minimum ecological adversities [47, 48]. Green economy can also address several of developing world challenges, such as $\mathrm{CC}$ vulnerability; management of natural resources; socioeconomic and environmental insecurities associated with water, energy and food; environmental pollution resulting in premature deaths, and also to reduce GHGs emissions $[49,50]$. Key to generate a large number of green jobs (jobs associated with environmental objectives and policies), financial assistance mobilized for green economy promotion is expected to be free from unwarranted conditionalities that are customary in traditional ODAs [51].

As the energy policy issues at national to global scales are increasingly determined to assess different aspects of sustainability, such as socioeconomic sustainability 
and need to reduce GHGs emission [52], it is evident that Nepal has to best utilize mainly renewable energy sources. Mainly in this area, Nepal's NDCs have an investment potential of US $\$ 46.1$ billion by 2030 , opening a big opportunity for the private sector, including the MDBs, local and regional financial institutions [53].

Firstly, Nepal has a huge potential for renewable energy with various estimates showing it could:

I. harness technically and economically viable 42,000 MW hydropower of 83,000 MW maximum potential [54] (of which only less than $1000 \mathrm{MW}$ is generated so far), where the ambition to install 12,000 MW of hydropower capacity alone has the investment opportunity of US $\$ 22.5$ billion, and another US\$100 million from small hydropower plants [55];

II. tap commercially viable $448 \mathrm{MW}$ wind power with the total potential exceeding $3000 \mathrm{MW}$ [56];

III. benefit from average $4.66 \mathrm{kWh} / \mathrm{m}^{2}$ day of solar across its $147,181 \mathrm{~km}^{2}$ landmass [57] with the investment opportunity of US $\$ 1.3$ billion [53];

IV. produce 9 to $12 \mathrm{TWh}$ of biogas energy with the investment potential estimated to be US\$707 million to the US $\$ 2.1$ billion from biomass and conversion of waste to energy [53].

Secondly, Nepal has a vast opportunity to invest in:

$\mathrm{V}$. increasing energy efficiency by improving existing energy systems, e.g., in green buildings (the US\$3.4 billion);

VI. developing low-carbon mass transports including electric vehicles (US\$2.5 billion) and climate-proof infrastructures including transport infrastructure (US\$10 billion).

Other top investment potentials are:

VII. managing urban wastes (US\$83 million) and promotion of climate-smart urban water management (US\$686 million) [53];

VIII. modernization of agriculture to so-called climatesmart agriculture (US $\$ 4.8$ billion), and effective management of forests protected areas and other types of lands can help sinking a large chunk of carbon (organic agriculture, habitat conservation, and restoration) among others $[46,58,59]$.

Likewise, other national policies such as the Urban Development Strategy 2017 may further increase the investment opportunity by up to US $\$ 12.6$ billion as it aims to increase the urban centers and improve infrastructures of the old ones [53].

As the post-Paris Agreement (2015) global climate actions are likely to build on the same, at least for the foreseeable future, it has opened investment opportunity of US\$23 trillion with majority of investment required for buildings (US\$16.3 trillion), transport (US\$3.7 trillion) and renewables (US\$1.8 trillion) [60]. In this context, Nepal's commitment to meet its targets under the Paris Agreement, or the NDC, which effectively captures the essence of green economy and transition to low-carbon economy, will be key to attract national and international CF to address climate challenges, secure climate-proof development and to achieve sustainable development goals [15]. See Table 2 for NDCs and SDGs or the 2030 Agenda linkages and overall impact on the sustainable living of people.

Similarly, WB estimates show that Nepal needs US\$13-18 billion per year for transport, electricity, information and telecommunications, water and sanitation, and irrigation [61]. Some argue that Nepal's increase of the budget for Strategic Road Network from $1.2 \%$ of GDP in $2007 / 2008$ to $2.3 \%$ in $2011 / 2012$, which is always suffering from underspending, is not sufficient and significant additional investment is required with low-carbon technologies such as electric train or electric vehicles become inevitable [62]. Add to it the cost of implementation of federalization process in Nepal, that requires the implementation of megaprojects for new administrative facilities, new roads connecting districts within and between the provinces, development of new economic opportunities, almost all climate proof, Nepal has huge scope for CF. Reconstruction and climate-proof development of facilities destroyed by the 2015 earthquake will need another set of financial instruments. Important to note, energy options (such as solar, wind, and micro-hydro), and economic areas (such as agriculture and forests) do not only meet their primary objective, they also contribute to small and medium enterprises development, particularly among the women, thus empowering women and promoting equitable development in the society $[46,63]$.

\section{Future perspectives}

Based on the situation described in previous chapters, we propose the following approaches for future both global and Nepal climate actions. These actions are particularly aiming at generating more $\mathrm{CF}$ with more equitable distribution of the benefits addressing the needs of poor and climate vulnerable. 


\section{Proliferation and optimization of global climate funds} Globally, as the countries strive to implement national development strategies, huge climate investment will be required every year over the next decades. The proliferation of climate funds is thus inevitable and a series of operational and architectural reforms are needed to ensure the efficiency in the channeling and delivery of finance [21, 64]. The future directions of CF need to clearly address issues such as:

I. over-reporting of climate-specific assistance, the value of loans, and climate relevance of bilateral funding;

II. slow growth in already very limited grant-based assistance, funding allocated for climate actions and funding allocated for LDCs;

III. increasing the share of aid in CF and lowering share of public finance;

IV. the clear gap between national needs and available CF;

V. the special vulnerability of and urgent interventions needed in Small Island Developing States and LDCs;

VI. limited availability of $\mathrm{CF}$ in the water sector and slowing spending in REDD+;

VII. the growing role of small and medium enterprises in supporting climate actions $[65,66]$.

\section{Developing green economy action plans in Nepal}

Considering Nepal's economy largely relies on income from the agriculture and remittance with energy, tourism, and hospitality sector having significant share [46, $58,59]$, aligning with the philosophy of the low-carbon economic development, we propose to develop green economy action plans centered around six key components-water, energy, food, forests, human settlements, and tourism. Then, Nepal can continue building on its strengths while preparing to tackle new challenges and benefit from national and international financing mechanism, including potential benefits from the Clean Development Mechanism (CDM) and the results-based payments for REDD+.

\section{Advance the public-private partnership framework}

As reflected during the UNFCCC negotiations, it is possible that ODA and CF, in near future, will either merge or at least one of them will become less relevant, eventually just changing the mode of support without much increase in proportional support. This will most likely create "a level playing field" in which the MDBs and the private sector will get more roles to play. Given this,
Nepal needs to advance the public-private partnership framework for implementing responses to $\mathrm{CC}$ and NDCs. Over 2015-2016, 79\% of global CF was raised in the country where it spent [67]. There are signals that the shift is already happening in energy and efficiency sectors. Solar and wind energetics are a clear success story in the USA, China, Japan, and Europe. Nepal needs better preparation to raise more local resources, enhance access to dedicated international funds on $\mathrm{CC}$, including for LDCs, and attract more FDIs while promoting more productive sectors to do green business.

\section{Attracting the mitigation finance}

Nepal supports efforts to limit global temperature to well below $2{ }^{\circ} \mathrm{C}$, leading to $1.5^{\circ} \mathrm{C}$, above pre-industrial levels. Thus, it needs to give more attention to work in mitigation and try to maximize benefits from international mechanisms such as CDM and results-based payments for REDD+. Mitigation related to GHGs emissions and adverse impacts reduction is also linked with future infrastructure, employment creation, and overall development in various sectors. However, Nepal is usually better prepared for attracting and implementing adaptation finance but is not making much effort to attract mitigation finance. The mitigation will still be a global priority for several decades to come, and Nepal needs better preparations for tap more mitigation finance, including funds dedicated to adaptation actions. This is particularly important given there is a growing trend of donors pledging to fund for adaptation funds but eventually turning away without much contributions $[68,69]$.

\section{Seeing beyond climate impacts-a case study from Kaski and Chitwan districts of Nepal}

Behind the concepts of $\mathrm{CF}$ and green economy, the people in local households have to be seen in the center of the actions. Climate change is only one of several changes that are part of a wider process of social transformation, particularly in rural livelihoods of Nepal. Fieldwork by Ensor et al. [70] in the Kaski and Chitwan districts of Nepal realized that respondents rarely referred to weather or climate as significant issues affecting livelihoods, and, although many aspects of social and livelihood change were discussed, no respondents attributed these to climate change (interviewed in December 2015) [70]. Major reasons of ongoing abandonment of rural land are rather lack of adequate labor and wages available for agricultural work, the effects of rising education in households, burgeoning mechanization, and high levels of migration into the urban or global labor and educational market [70,71]. Although migration is by no means a new phenomenon in this region, the scale of migration has changed radically in recent years. The 
number of emigrants from Nepal increased by more than 60\% during the decade 2001-2011 [72]. The Nepali 2011 census data records farm income as comprising $38 \%$ and $28 \%$ of total household income in Kaski and Chitwan, respectively, with non-farm (29\% and $43 \%)$ and remittance income ( $21 \%$ and $18 \%$ ) dominating the remainder [72]. In contrast, 30 years ago the majority of households would have had about $80 \%$ of their incomes from farming [73].

Thus, while extreme weather events and climate change are causing changes in farming practices, these practices are even more influenced by out-migration, changing income opportunities, and desires to shift away from land dependency. In this context, it is evident that investing adaptation resources exclusively into addressing the production constraints anticipated under climate change would be to misunderstand the multidimensional nature of the challenges faced by rural households and overlook entirely the needs of those who have essentially left, or in the future will exit agriculture. However, important, alternative questions are raised when the biophysical and rural transformation perspectives are considered together. Can adaptation interventions, such as multistakeholder visioning and scenario planning, identify desirable livelihood trajectories in a context of intersecting climate and political-economic change [74, 75]? What capacities do households need to take advantage of opportunities for development, such as those arising from education or new employment options? And how can adaptation support be to channeled to meet their particular needs, for example through alignment with interests expressed through emerging grassroots movements or NGOs [70, 76]? Only by stepping back from an exclusively biophysical understanding of adaptation can these questions be opened up and explored, and the adaptation CF can be then invested effectively.

\section{Summary and conclusion}

Nepal is now well prepared to start the journey of green economy development because have already: (I) developed the institutional mechanisms; (II) formulated the CC policy and other supporting sector policies; (III) designed the various adaptation frameworks (NAPA, LAPA, and NAP in progress); (IV) tested several CC adaptation and mitigation pilots (SPCR, NCCSP, Hariyo Ban and REDD+ activities); and (V) submitted the NDC to the UNFCCC secretariat. Therefore, Nepal is best positioned to address the $\mathrm{CC}$ problems, implement a low-carbon approach and create eco-friendlier and equitable society, but requires new and additional technical and financial resources. Green economy, climate-proof infrastructures, and even 2030 Agenda for Sustainable Development are now intermixed and converge at the same point. In summary, the evidence discussed demonstrates that Nepal has started structuring CF, and made it an important part of the national budget. Clear codes are being assigned to each climate-related programs and projects by the ministries involved. Once the government has established own programs on CC, other actors such the I/NGO and the civil society are likely to follow the footsteps for more coherent, coordinated, and effective climate actions.

Nepal has already secured institutional preparations and policy frameworks to maximize the benefits from the CF and climate-related development finance, mainly aided by the European countries development partners. However, a relatively small share of funding under the UNFCCC mechanism as well as a lack of established mechanisms to facilitate private CF could limit Nepal's access to CF in the future. It is also worrying that the contribution from the European countries has not increased significantly after 2014. Considering these realities, Nepal needs to make special efforts to increase the contributions from three key areas-funding under the UNFCCC window, the assistance of European countries, and finally, investments from private sector beyond the MDBs.

Finally, when investing particularly the adaptation resources, it is necessary to see beyond climate impacts. Anticipating the climate change being the only or major challenge faced by recent households can be a misunderstanding of the multidimensional nature of the biophysical and socioeconomical transformation especially of Nepal's rural society. It can result in overlooking the needs of those who have changed or in the future will change their traditional livelihood, and thus wasting the already scarce CF.

\section{Additional files}

Additional file 1. Distribution of investments from public and private sources.

Additional file 2: Table S1. Government of Nepal's Annual Budgeting on Climate Change.

Additional file 3: Table S2. Major Climate Investments in Nepal.

Additional file 4: Table S3. 11 Priority areas for the Future for Climate Finance in Nepal.

Additional file 5: Table S4. 11 Criteria to define Climate Finance in Nepal.

\section{Abbreviations}

ADB: Asian Development Bank; AF: Adaptation Fund; CCBC: Climate Change Budget Code; CDM: Clean Development Mechanism; CF: Climate Finance; CIF: Climate Investment Funds; DANIDA: Danish International Development Agency; DFID: Department for International Development; DFls: Development Finance Institutions; EU: European Union; FDIs: Foreign Direct Investments; FSF: Fast Start Finance; GCCA+: Global Climate Change Alliance Plus; GCF: Green Climate Fund; GDP: Gross Domestic Product; GEF: Global Environment Facility; GIZ: German Corporation for International Cooperation; GHGs: 
Greenhouse Gases; LAPA: National Framework on Local Adaptation Plans for Action; LDC: Least-Developed Country; LDCF: Least-Developed Countries Fund; MDBs: Multilateral Development Banks; NAP: National Adaptation Plan NAPA: National Adaptation Programme of Action; NCCSP: Nepal Climate Change Support Programme; NDCs: Nationally Determined Contributions; NGOs: Non-Governmental Organizations; NORAD: Norwegian Agency for Development Cooperation; ODA: Official Development Assistance; OECD: Organisation for Economic Co-operation and Development; PPCR: Pilot Program for Climate Resilience; REDD: Reducing Emissions from Deforestation and Forest Degradation; SCCF: Special Climate Change Fund; SDGs: Sustainable Development Goals; SPCR: Strategic Programme for Climate Resilience; UK-Aid: United Kingdom Aid; UNEP: United Nations Environment Programme; UNFCCC: United Nations Framework Convention on Climate Change; USAID: United States Agency for International Development; WB: World Bank.

\section{Acknowledgements}

This research, which is part of a Ph.D. study of Tek Jung Mahat, was cofinanced by the Erasmus Mundus Action 2 (Experts4Asia) and RECETOX Research Infrastructure (LM2015051 and CZ.02.1.01/0.0/0.0/16_013/0001761).

\section{Authors' contributions}

TJM prepared the first draft of the manuscript. All authors contributed to specific aspects. MB finalized the manuscript. All authors read and approved the final manuscript.

\section{Funding}

This research was co-financed by the Erasmus Mundus Action 2 (Experts4Asia) and RECETOX Research Infrastructure (LM2015051 and CZ.02.1.01/0.0/0.0/16_ 013/0001761)

\section{Availability of data and materials}

The datasets supporting the conclusions of this article are included in the article.

\section{Ethics approval and consent to participate}

Not applicable.

\section{Consent for publication}

This manuscript consists of original, unpublished work, in whole or in part, which is not under consideration for publication elsewhere. All authors are aware of and accept responsibility for this manuscript and approve consent for publication.

\section{Competing interests}

The authors declare that they have no competing interests.

\section{Author details}

1 Faculty of Science, Research Centre for Toxic Compounds in the Environment-RECETOX, Masaryk University, Kamenice 5, 62500 Brno, Czech Republic

${ }^{2}$ Centre for Climate Research and Advocacy, Central Department of Environmental Science, Tribhuvan University, Kathmandu, Nepal. ${ }^{3}$ Ministry of Environment, Kathmandu, Nepal.

Received: 26 September 2018 Accepted: 19 June 2019

Published online: 23 July 2019

\section{References}

1. Steele P (2015) Development finance and climate finance: achieving zero poverty and zero emissions. London

2. UNFCCC (1992) United Nations Framework Convention on Climate Change. Preamble. FCC/INFORMAL/84/Rev.1 GE.14-20481 (E). UNFCCC Secretariat

3. Moellendorf D (2012) Climate change and global justice. Wiley Interdiscip Rev Clim Chang 3:131-143. https://doi.org/10.1002/wcc.158

4. Curran $P(2018)$ What is climate finance?

5. UNCTAD (2015) "New and additional" climate finance: a continuing lack of clarity. Geneva

6. Brown J, Bird N, Schalatek L (2010) Climate finance additionality: emerging definitions and their implications
7. Westphal MI, Canfin P, Ballesteros A, Morgan J (2015) Getting to \$100 billion: climate finance scenarios and projections to 2020

8. Germanwatch (2015) Global climate risk index 2016. Berlin, Germany

9. Germanwatch (2016) Global climate risk index 2017. Berlin, Germany

10. Maplecroft (2012) Maplecroft Global Risks Atlas 2011. Bath, United Kingdom

11. MoE (2010) National adaptation programme of action (NAPA). Ministry of Environment, Kathmandu

12. MoE (2012) Mountain environment and climate change in Nepal. In: Country report for the international conference of mountain countries on climate change, Kathmandu

13. CBS (2017) National climate change impact survey 2016: a statistical report. Central Bureau of Statistics Nepal, Kathmandu

14. MoPE (2017) Synthesis of the stocktaking report for the National Adaptation Plan (NAP) Formulation Process in Nepal

15. MoPE (2016) Nepal Nationally Determined Contributions (NDCs). Submitted to the UNFCCC Secretariat in October 2016

16. NPC (2015) Sustainable development goals, 2016-2030. National (Preliminary) Report. Kathmandu, Nepal

17. UNFCCC (2016) UNFCCC Standing Committee on Finance: 2016 biennial assessment and overview of climate finance flows report

18. GGA Alliance (2013) The Green Investment Report: The ways and means to unlock private finance for green growth

19. Buchner BK, Oliver P, Wang X, et al (2017) Global landscape of climate finance 2017

20. IEA (2017) World Energy Investment 2017 report: executive summary

21. Halonen M, IIIman J, Klimscheffskij M et al (2017) Mobilizing climate finance flows: Nordic approaches and opportunities. Nordic Council of Ministers, Copenhagen

22. Bird N, Watson C, Schalatek L, Keil K (2017) Climate finance thematic briefing: adaptation finance. Climate Finance Fundamentals 3

23. EU International climate finance / Climate Action

24. Dejgaard HP, Applet J (2018) An analysis of the climate finance reporting of the European Union

25. EU (2015) European Union climate funding for developing countries 2015

26. EU (2017) Reflection paper on the future of EU finances

27. EU (2017) Press Release, 12 December 2017: questions and answers on EU and climate finance. In: Eur. Comm.—Fact Sheet

28. GCCA + Nepal Climate Change Support Programme (NCCSP): building climate resilience

29. OECD (2016) 2020 projections of Climate Finance towards the USD 100 billion goal, Technical Note

30. UNFCCC (2015) Press Release, 13 December 2015: Historic Paris agreement on climate change: 195 nations set path to keep temperature rise well below 2 degrees celsius

31. Bird N (2011) The future for climate finance in Nepal

32. IDS-Nepal, PAC, GCAP (2014) Economic impact assessment of climate change for key sectors in Nepal. Kathmandu, Nepal

33. Crawford SE, nee Cofalla CB, Aumeier B et al (2017) Project house water: a novel interdisciplinary framework to assess the environmental and socioeconomic consequences of flood-related impacts. Environ Sci Eur 29:23. https://doi.org/10.1186/s12302-017-0121-1

34. Riediger J, Breckling B, Nuske RS, Schröder W (2014) Will climate change increase irrigation requirements in agriculture of Central Europe? A simulation study for Northern Germany. Environ Sci Eur 26:18. https://doi. org/10.1186/s12302-014-0018-1

35. PRC (2016) Access to climate finance in Nepal. Kathmandu, Nepal

36. CPEIR (2011) Nepal climate public expenditure and institutional review. Kathmandu

37. Karanjit S, Lee J, Pant S, Steele P (2014) Country brief: effective governance of climate finance for local delivery in Nepal. Kathmandu, Nepal

38. MoF (2013) Estimates of expenditure for fiscal year 2012/13. MoF, Kathmandu

39. MoF (2014) Estimates of expenditure for fiscal year 2013/14. MoF, Kathmandu

40. MoF (2015) Estimates of expenditure for fiscal year 2014/15. MoF, Kathmandu

41. MoF (2016) Estimates of expenditure for fiscal year 2015/16. MoF, Kathmandu 
42. MoF (2017) Estimates of expenditure for fiscal year 2016/17. MoF, Kathmandu

43. NDRI, PRC (2017) Situation analysis for Nepal on climate finance

44. NPC (2012) Climate change budget code: documenting the National process of arriving at multi-sectoral consensus, criteria and method. Government of Nepal, National Planning Commission with support from UNDP/UNEP, Kathmandu

45. NPC (2013) Climate change budget code, application review

46. NPC (2011) Nepal status paper-United Nations conference on sustainable development 2012. Kathmandu, Nepal

47. UNEP (2011) Towards a green economy: pathways to sustainable development and poverty eradication - a synthesis for policy makers. UNEP, Nairobi

48. ESCAP, ADB, UNEP (2012) Green growth, resources, and resilience: environmental sustainability in Asia and the Pacific. United Nations Economic and Social Commission for Asia and the Pacific (ESCAP), the Asian Development Bank (ADB) and United Nations Environment Programme (UNEP), Bangkok

49. OECD (2011) Towards green growth: a summary for policy makers. OECD, Paris

50. OECD (2012) Green growth and developing countries: a summary for policy makers. OECD, Paris

51. UNCSD (2012) The future we want. In: Outcome document of the United Nations conference on sustainable development Rio de Janeiro, Brazil, 20-22 June 2012

52. Castellani V, Piazzalunga A, Sala S (2013) Research findings and decision making: the case of renewable energy. Environ Sci Eur 25:22. https://doi. org/10.1186/2190-4715-25-22

53. IFC (2017) Climate investment opportunities in South Asia. Washington, D.C, IFC

54. Guntilake H, Roland-Holst D (2013) Hydropower development and economic growth in Nepal. Berkeley, California

55. Araldsen TPRL (2016) Biogas in Nepal: limitations for the expansion of community plants. Norwegian University of Life Sciences

56. Upreti BN, Shakya A (2009) Wind energy potential assessment in Nepal

57. Adhikari KR, Gurung S, Bhattarai BK (2014) Solar energy potential in Nepal and global context. J Inst Eng 9:95-106

58. Bhuju DR, Thapa-Parajuli RB, Sharma P, Aryal P (2015) Nepal's green economy initiative and framework proposed. Nepal J Environ Sci. https:// doi.org/10.13140/rg.2.2.31608.90883

59. Karki M (2013) Green economy for sustainable development in Nepal: role of forestry sector. Initiation. https://doi.org/10.3126/init.v5i0.10259

60. Kerr T, Maheshwari A, Sottong J (2016) Climate investment opportunities in emerging markets. An IFC analysis. Washington, D.C

61. Dixit AM (2017) Infrastructure financing strategies for sustainable development in Nepal
62. Pokharel R, Acharya SR (2015) Sustainable transport development in Nepal: challenges, opportunities and strategies. J East Asia Soc Transp Stud 11:209-226

63. Dulal HB, Brodnig G, Thakur HK, Green-Onoriose C (2010) Do the poor have what they need to adapt to climate change? A case study of Nepal. Local Environ 15:621-635. https://doi.org/10.1080/13549839.2010.49881 4

64. Amerasinghe N, Thwaites J, Larsen G, Ballesteros A (2017) Future of the funds: exploring the architecture of multilateral climate finance. World Resources Institute, Washington, DC

65. Carty T, Le Comte A (2018) Climate Finance Shadow Report 2018: assessing progress towards the $\$ 100$ billion commitment

66. Watson C, Bird N, Schalatek L (2017) 10 things to know about climate finance in 201

67. Climate finance landscape climate finance landscape

68. Goldenberg S (2015) Rich countries'\$100bn promise to fight climate change "not delivered"| Environment. Guard

69. Terpstra P (2013) Are developed nations falling short on their climate finance commitments? In: World Resour. Inst. Off. Blog

70. Ensor JE, Wennström P, Bhatterai A et al (2019) Asking the right questions in adaptation research and practice: seeing beyond climate impacts in rural Nepal. Environ Sci Policy 94:227-236. https://doi.org/10.1016/j.envsc i.2019.01.013

71. Korzenevica M, Agergaard J (2017) 'The house cannot stay empty': a case of young rural Nepalis negotiating multilocal householding. Asian Popul Stud 13:124-139. https://doi.org/10.1080/17441730.2017.1303110

72. Central Bureau of Statistics (2014) Population monograph of Nepal, Vol II (Economic Demography). Central Bureau of Statistics, Kathmandu

73. Rigg J (2006) Land, farming, livelihoods, and poverty: rethinking the links in the Rural South. World Dev 34:180-202. https://doi.org/10.1016/j.world dev.2005.07.015

74. Brown I, Martin-Ortega J, Waylen K, Blackstock K (2016) Participatory scenario planning for developing innovation in community adaptation responses: three contrasting examples from Latin America. Reg Environ Change 16:1685-1700. https://doi.org/10.1007/s10113-015-0898-7

75. Rickards L, Ison R, Fünfgeld H, Wiseman J (2014) Opening and closing the future: climate change, adaptation, and scenario planning. Environ Plan C Gov Policy 32:587-602. https://doi.org/10.1068/c3204ed

76. Dodman D, Mitlin D (2013) Challenges for community-based adaptation: discovering the potential for transformation. J Int Dev 25:640-659. https ://doi.org/10.1002/jid.1772

\section{Publisher's Note}

Springer Nature remains neutral with regard to jurisdictional claims in published maps and institutional affiliations.

\section{Submit your manuscript to a SpringerOpen ${ }^{\circ}$ journal and benefit from:}

- Convenient online submission

- Rigorous peer review

- Open access: articles freely available online

- High visibility within the field

Retaining the copyright to your article

Submit your next manuscript at springeropen.com 